\title{
Jean-Pierre Changeux on how and why our brains enable us to make judgments about what is good, true or beautiful
}

\author{
Egbert Giles Leigh Jr.
}

\begin{abstract}
Book details
The Good, the True and the Beautiful: A Neuronal Approach, by Jean-Pierre Changeux. New Haven, CT: Yale University Press and Paris: Editions Odile Jacob. 2012. pp. xii + 386. ISBN 978-0-300-16139-7. H/b \$38.00.
\end{abstract}

Keywords: Mind, Matter, Neurobiology, Social life, Darwin, Ethics, Art, Communication

In this book, a French neurobiologist, Jean-Pierre Changeux, tackles one-and by no means the least perilous-of biology's last frontiers. His subject is the neurobiological basis of why human beings make judgments about what is good, true or beautiful, and how we make them. Changeux was trained as a molecular biologist by Jacques Monod, who, of all the founders of molecular biology, best understood both evolution and animal behavior. Monod knew and appreciated the ethologist Konrad Lorenz. In 1976, Changeux was called to the Collège de France, where he used his molecular biological techniques to understand the human brain and nervous system. The French edition of his book explicitly draws on courses he gave there. His book claims the attention of this Journal's readers, first through its concern with consciousness, whose material basis is still far from clear even though it allows us to understand ourselves, other people and even other animals (Weyl 1949, p. 283); second, through its focus on understanding the human brain, the last redoubt from which some theologians still hope to demonstrate limits on the efficacy or relevance of Darwinian evolution by natural selection.

The Good, the True and the Beautiful is a comprehensively reorganized, considerably abridged translation by Laurence Garey of Changeux's (2008) Du vrai, du beau, $d u$ bien: une nouvelle approche neuronale. By clarifying

*Correspondence: bufotyphonius@gmail.com

Smithsonian Tropical Research Institute, Apartado 0843-03092,

Balboa, Ancon, Panama, Republic of Panama the neurobiological basis of human judgments on goodness, truth and beauty, Changeux hopes to build a bridge between the humanities and neurobiology, even though he realizes that some will view the project as "an abusive, even an illegitimate impertinence" (Changeux 1997, p. 274). His credentials as a humanist are impressive. Changeux's (1985, 2002; Changeux and Ricoeur 2000) books skillfully deploy the insights of people as varied as Plato, Aristotle, Descartes, Spinoza and Diderot. A serious art collector, Changeux (1994) has written on the neurobiology of appreciating and collecting art. Most remarkably, Changeux was sufficiently interested in how to convince humanists of the material basis of mind, thought and feeling that he engaged a Christian moral philosopher, Paul Ricoeur, in a published dialogue on the subject (Changeux and Ricoeur 2000). This dialogue is an unusually serious and effective attempt to achieve mutual understanding.

After three pages of introduction, the English version starts with Changeux's chapter on the Beautiful. In both versions, this chapter centers on appreciating works of art. Changeux emphasizes that art depends on association of memories: association enabled by the great expansion of the human brain's associational cortex, which involves both emotion and reason. Any reader of T. S. Eliot knows how his poetry depends on evoking associations of memories, images and emotions: as with poetry, so with art and music. Empathy, sympathy and reason are essential ingredients of morality, as Darwin (1871) realized. Neurobiological bases of empathy and 
sympathy are being progressively elucidated, as this book shows and later work such as Marsh et al. (2014) abundantly confirms.

Trying to define beauty, Changeux summarizes views from Plato onward, singling out Plato's dialogue "Greater Hippias," from which he extracts two definitions: "formal appropriateness, where the unity of the whole triumphed over the multiplicity of its parts," and more especially, the harmony of those parts in the service of a beneficial function. Haldane's (1932: 162) remarkable understatement, "in the cases of sexual selection and the evolution of flowers, survival value has been determined by animal aesthetics, which are not altogether unlike our own" suggests that Plato's view echoes ancient instinct. Then, after discussing the physics and neurobiology of seeing and hearing, Changeux turns to the role of empathy and sympathy in creating and appreciating art. He sees art as first gripping the viewer by an emotion-delight in something's or someone's beauty, sorrow at a depicted grief, anger at a depicted wrong. This grip depends on the artwork's ability to arouse the reader's empathy or sympathy with the artist's own response. Creating such a work of art involves not only inspiration but a great deal of trial and error-comparing the effectiveness of different designs or coloring as a writer compares the effectiveness of different wordings (p. 35). Empathy and sympathy have neurobiological bases: they are often aroused by facial expressions, such as pain or joy. Neurobiologists have long been preoccupied by the ability to recognize faces and infer emotions from facial expressions (p. 29). Changeux discusses studies by a French painter of Louis XIV's time, Charles Le Brun, of the connection between facial expressions and the underlying emotions they reflect (pp. 67-70), which Darwin (1872) mentioned in his more general study. After the initial emotion, reason is used to understand, discipline and order the emotional reaction (p. 40).

Changeux (pp. 39-52) compares art and music: in both, beauty reflects appropriate harmony among their parts. Music, like painting, conveys emotions, and response to music has neurobiological bases. Martha Nussbaum (2013) gives a striking example from Mozart's opera, the Marriage of Figaro, of how words and music can conjointly lend emotional punch to a reasonable belief. Many consider this opera a frivolous, defanged, version of a play Beaumarchais wrote to ridicule the hierarchical order of prerevolutionary France. In the opera, Figaro is as preoccupied by desire for honor, power, and revenge for wrongs real or imagined, as the Count and his allies whose designs Figaro seeks to foil. On the other hand, the opera's women, particularly the Countess and her servant Susanna are habitually concerned with others, helpful, unconcerned with hierarchy and not vengeful-their attitudes are truly revolutionary, not just more of the same. Nussbaum (2013, pp. 40-53) shows how powerfully the music reinforces the libretto's message. Why did not others notice what she saw? True, Martha Nussbaum is uncommonly perceptive. The real lesson here, however, is that great art makes demands of its spectators as well as its creator, as Changeux (p. 61) emphasizes. Appreciating art involves an effortful collaboration between artist and spectator.

The following chapter, on the Good, opens by criticizing Hume's distinction between what is and what ought to be (p. 71). This criticism will upset many, but even Plato, for all his emphasis on divine norms, remarked that a gang of thieves will cooperate effectively only if they can trust each other (an insight shared by an ancient Chinese philosopher: Waley 1982, p. 74). Here, Plato inferred a (within-group!) golden rule from an empirically based thought-experiment. Natural selection favors cooperation over cheating among members of a monkey group or honeybee colony, suggesting how, as Darwin (1871) argued, moral conclusions can emerge from empirical experience. Indeed, the idea that one cannot reason meaningfully about moral questions is one of the oddest of modern superstitions (Midgley 2003), one decisively refuted by Shakespeare's plays. Here, Changeux discusses the origin of ethics, the natural, neurobiologically based human predisposition to moral judgment, and how cultural evolution has shaped and changed social and cultural norms during human history (p. 72). His brief discussion mentions the unusual human ability to infer the, knowledge, beliefs and intentions of others from their actions and facial expressions, and plan actions accordingly (p. 74); the instinctive tendency of a child (or other social mammal) to cease hurting companions when they show signs of pain or distress (p. 75); and the role of consciousness in imagining different modes of action and evaluating their moral consequences. Changeux cites how 4-year-old children distinguish social conventions such as dietary taboos, which they see as applying only to specific social groups, from universally obligatory moral rules against robbery, murder, slander \&c (p. 77) - a distinction he hopes will help us form general moral rules applicable to all humanity, not just one tribe or nation (p. 79). Changeux and Ricoeur (2000), however, present the neurobiology involved far more thoroughly.

The big puzzle about this chapter is what it omits. Following Spinoza, Changeux and Ricoeur (2000, p. 222) argue that the most basic ethical virtue is selfpreservation. They quote Spinoza's statement that “The [effort] to preserve oneself is the primary and sole basis of virtue." This remark sounds horridly selfish, but Damasio (2003, p. 171), following Spinoza, remarks that the drive for self-preservation "leads to virtue 
because in our inalienable need to maintain ourselves, we must, of necessity, help preserve other selves." Plato's thieves knew this, as did Darwin (1871). Any animal that helps fellow group members lest its group dwindle to defenseless size (Leigh 2010, p. 15) acts as if its future depends on those others. Ethics can be founded on the instinct of self-preservation-after all, we are commanded to love others as we love ourselves. The instinctive desire for self-preservation must have a neurobiological basis (Damasio 2003, p. 171). Given Changeux's respect for Spinoza, why did this chapter omit the principle by which natural selection would favor a proper ethics in sufficiently intelligent social animals (Darwin 1871)?

In the French edition, Changeux discusses the Good before the Beautiful: his views on art have a strong moral element, and presuppose some understanding of the neurobiological bases of ethical responses. The English edition's discussion of the Good begins with ethical norms (pp. 71-80), whereas the French version prepares readers for this discussion. First, it surveys ideas on how and why human social life and associated ethical norms developed (pp. 103-115, 80-103 in the English version). Here, Changeux remarks how "the Golden Rule of moral conduct is common to most philosophical and religious traditions" (p. 107). This survey also includes an account of the various stages by which children's awareness of others advances until, at age four, they can infer intentions, beliefs and emotions of others; and evidence for the neurological basis of feeling another's pain (pp. 107-115 in the English version)-all useful background for discussing ethical norms. Next, Changeux discusses what circumstances cause natural selection to favor social life in animals (pp. 115-123). He considers kin selection, which drove the evolution of insect societies (Hamilton 1964), reciprocal altruism (tit for tat), and selection among groups. Darwin (1871, p. 166) invoked selection among tribes of hunter-gatherers, which numbered about 25 individuals apiece (Boehm 2012, p. 80), to help explain the evolution of human morality-a reasonable view if the egalitarianism within such tribes equalizes reproductive success among a tribe's members (Boehm 1997). Changeux's original order was judicious. Many will consider a materialistic explanation of human ethics only if they understand how natural selection could favor such ethics. Although in the 17th century Spinoza's Ethics showed why competition would favor social cooperation (Damasio 2003, p. 171) and Adam Smith (1776) made this plain as day a century later, many biologists still prate endlessly about the "paradoxical" prevalence of cooperation in a world shaped by the competitive process of natural selection. Given this situation among biologists, could ordinary readers know better?
The English edition's chapter on Truth starts with a prologue on the "naturalistic conception of the world" (pp. 124-138). This prologue set the stage for the whole of the French edition, as it sets forth the philosophy, and some of the themes, of its project. Here, Changeux approvingly quotes Joëlle Proust: "A philosophical theory is naturalistic when it recognizes as legitimate only those objective undertakings and explanatory principles normally recognized and adopted in the natural sciences" (p. 135). The main heroes of this prologue, however, are Charles Darwin and Karl Popper. Darwin showed how differential replication of different heritable variants creates a feedback between an environment and the adaptation thereto of its organisms. Thanks to this feedback, selection is not merely the simple filter imagined by Midgley (2014, p. 71). Popper described how analogous feedback between different conjectures and their confrontation with observation or experimental test advanced scientific understanding by favoring ideas that represent reality better. These feedbacks have many analogues, ranging from the many "trial" representations of our surroundings from which our brain selects the best to present to our consciousness, to the many trials from which an artist or writer chooses the one that best achieves the desired effect. Changeux invokes many guises of trial and error.

In the English version, this prologue introduces a subchapter called "The Raging Beast-Cognition and Language," the title of the French original's Part II (of four). This is the beast Changeux seeks to tame. Henceforth, the two versions' organization match. First, Changeux reviews past thought about consciousness (pp. 138-146). He especially praises William James, who realized that one's sense of self is based on perceived consciousness, emphasized the role of conscious memory in our sense of time, and argued that "the question of fact in the free-will controversy... relates solely to the amount of effort or attention which we can at any time put forth" (p. 143). James's view of free-will is shared by Midgley (2014, p. 104): "the idea of free will... concerns effort, which is a perfectly real causal factor." Then Changeux documents the neural basis of different aspects of consciousness. $\mathrm{He}$ observes that lesions of different parts of the brain impair conscious (but often not unconscious) recognition of objects, familiar faces and perils like open flames (pp. 146-155). He shows how consciousness is revealed by the brain's electrical activity-similar when awake and focusing on sensory inputs, or dreaming and attending to memories, but very different in unconscious deep sleep (pp. 155-160). Brain imagery reveals the parts of the brain involved in subjective experience, focused attention and perception (pp. 160-165). Finally he presents his own views, remarking that "Consciousness attained its apogee through deliberation, which depends on judgment, 
which is the result of impulse and inhibition" (p. 171). He views consciousness as a global neuronal workspaceMonod (1971: 154-159 called it a "simulator"-that imagines possible actions, and predicts and evaluates their consequences. This workspace integrates perceptions, memories, and evaluations of past actions and organizes suitable responses (pp. 171-176). He uses specific models, based on his understanding of brain architecture, to learn what neural processes are needed to deal with specific tasks which psychologists assign patients in order to diagnose their neural disorders. These processes involve long-axon associative neurons which connect different parts of the brain, and short-axon neurons involved in specific subroutines, such as vision and movement, involved in executing the assigned task. Such long-axis neurons are most common in the brain's frontal lobes, which are involved in tasks requiring conscious effort (p. 179).

Alison Jolly (1966) argued that intelligence evolved in primates to cope with problems of social life. It is therefore fitting that Changeux next considers neurobiological enablers of social life, especially communication. Although language encodes concepts and their relationships to communicate them, the meaning of speech depends on context: just as we unconsciously extract a pictorial hypothesis of our surroundings from a maze of visual data, so we infer (often equally unconsciously) the meaning of a spoken message using our picture of the speaker's knowledge, beliefs and intentions (pp. 180184). Language involves effortful cooperation between speaker and hearer that requires both "theory of mind" and consciousness, which integrates input from unconscious subroutines in different parts of the brain-such as that which infers an object from its various perspective views, that which stores memory, and that which evaluates remembered actions-to choose an appropriate response from the available possibilities. Theory of mind has a neural basis that includes mirror neurons, which fire similarly if an animal performs a complex action or if it sees another perform it (p. 185). Cerebral imaging reveals activity in several parts of the brain during tasks requiring "theory of mind." Specific neural lesions impair abilities related to theory of mind, such as distinguishing self from nonself (pp. 186-187).

Noam Chomsky showed that children can learn to speak thanks to an "innate grammar," a template for arranging words in meaningful sentences (p. 191). Language hinges on asymmetry between the brain's right and left halves-already evident in the skulls of Homo habilis, and progressively greater in $H$. erectus and H. sapiens (p. 196). The neurobiological basis of speech is revealed by lesions in different parts of the brain impairing different aspects of speech, such as forming words, understanding them, or forming and relating concepts (p. 195). These lesions, like those impairing theory of mind, reveal a hierarchy of layers of organization in the brain, from simple, rigid, automatic routines to complex, flexible, voluntary processes, the highest level being consciousness, which deliberates among competing alternatives. Higher levels evolved later, and lesions at higher levels induce failure to integrate different inputs, undoing the achievements of evolution (pp. 197-198). This helps us understand why behaviors of some small mammals are more automatic than they seem. Meerkats teach young how to handle difficult prey by bringing them progressively less disabled prey to deal with, but mothers judge how much to disable prey by the age of the young as revealed by the timbre of their calls, rather than direct assessment of their ability to handle prey (Thornton and McAuliffe 2006).

Integrating neural inputs presuppose suitable interconnections, synapses, among our brain's $10^{11}$ neurons, which organize our sensations and coordinate them with our activity. Genes program the formation of synapses, about 10,000 of them per neuron, but synapses last only if used (p. 203). Blind children interpreting Braille coopt parts of their visual cortex to integrate and interpret tactile stimuli (p. 208), using synapses that would otherwise die.

Now, Changeux turns to writing-forming visual signs denoting concepts, whose arrangement conveys relationships among the concepts (p. 209). Because writing can store knowledge for generations, often in movable form, it plays a vital role in cultural inheritance and cultural evolution. He describes the progress of visual signs from prehistoric cave paintings with associated abstract signs (p. 211) to the independent invention of picto-ideographic writing in Sumeria and Egypt before 3000 BC (p. 213), and the Sumerian invention of cuneiform, where the signs denoting both objects and concepts are simpler and more abstract (p. 214). Later, ideograms in some monosyllabic languages became syllabograms where signs represent sounds. Alphabets, where letters denote sounds (p. 218), were invented about 1500 BC. Changeux shows how successive stages in this development were stimulated by the need for people of different cultures and languages to communicate (pp. 214-215, p. 219), Neurobiological bases of writing and reading, like those of speech and understanding, are revealed by the effects of different lesions, and cerebral imagery of people reading (pp. 220-225).

Now Changeux turns to topics bearing less obviously on how minds work, discussing evolution, especially of the nervous system, from invertebrates to human beings. $\mathrm{He}$ models the morphogenetic processes causing the divergence of vertebrate from invertebrate brain and nerve cord (p. 246). He ascribes the increased size and 
complexity of the human brain mostly to the increased complexity of its the network of interconnections (p. 243), which genes control least precisely (pp. 256-257) and emphasizes how spontaneous electrical activity in the developing nervous system stimulate and preserve neural interconnections (pp. 257-265).

Next Changeux considers topics central to his own progress from molecular biochemist to neurobiologist. He discusses receptors of neurotransmitters-chemicals that influence transmission of nerve impulses across synapses. He focuses on the function and molecular structure of receptors of acetyl choline and shows how they integrate various chemical inputs (pp. 272-292). A molecular model on how a sea slug learns a conditioned reflex (pp. 295-301) shows how far we are from a mechanistic understanding of how we learn concepts. A section on the chemistry of consciousness (being awake rather than asleep) focuses mostly on how general anaesthetics affect transmission of neural impulses (pp. 301-313).

Then Changeux summarizes his previous work, giving a useful resumé of this book's arguments; reflects on death and its significance; and closes with remarks about how science has promoted civil rights, and his hope that his work will enhance universal human understanding.

What has this book told us? Using evidence ranging from brain lesions to neuroanatomy, electrophysiology, the effect of anaesthetics and mind-altering chemicals and cerebral imaging, he shows that the brain is involved in and essential to emotional responses and conscious effort of all sorts, ranging from appreciating art to speaking, writing, and judging between right and wrong, both intellectual and ethical. Neurobiology has revealed not only the loci of various aptitudes but how the brain coordinates and integrates contributions from these aptitudes. He has not yet destroyed "the barrier that divides our subjective experience from the objective physiological events that occur in out body" (Lorenz 1978, p. 169) although he finds objective signs of various subjective states. He gratifyingly refuses to focus on the objective to the exclusion of the subjective. To prove, however, that mind is made of matter, he must demonstrate the material basis of consciousness, and that he has not yet done.

Following carefully in the footsteps of Darwin (1871), he does show when and how selection would favor the ability of intelligent social animals to make judgments on the good, the true and the beautiful. I have no idea whether consciousness has a purely material basis. Changeux, however, has shown that consciousness is so enmeshed in matter that his project should be pursued. Phenomena such as dissipative structures-intricate, selforganizing patterns appearing in chemical systems which input of energy keeps far from equilibrium (Prigogine 1978) suggest properties of matter that Aristotle never dreamed of. Christians should expect that the matter they believe God created, when suitably arranged, can do more wonderful things than anyone ever expected, whether or not consciousness itself has a material basis.

Changeux's prejudices will put off some readers. Unlike Changeux and Joëlle Proust (p. 34), the atheist Haldane (1927) thought that science was not the only source of truth. Other prejudices may do more damage. Describing human beings as "conscious automatons" seems to ignore the personal judgments involving unprogrammable ideals such as beauty, simplicity and appropriateness, particularly important in art, mathematics and science but essential to all human behavior (Putnam 1992, pp. 1-18). Changeux believes that the truths of mathematics are culture-dependent (Changeux and Connes 1995, pp. 31ff). The mathematician Alain Connes rightly denies this (Changeux and Connes 1995, p. 5). After all, there are exactly 17 kinds of "wallpaper symmetry" on a plane surface (Weyl 1951), no matter on what planet, no matter who if anyone is there to deduce or recognize this fact. Connes accepts that minds are material. Can material minds can apprehend immaterial truth? This possibility should not be dismissed unheard.

The question a humanist would ask about this book is whether its view of what it is to be a human being is too limited. Were this true, Changeux's project would be dangerous. The tunnel-vision views of economic determinists, communist and capitalist, of what human beings want from life, have been socially devastating (Bernanos 1953; Nussbaum 1995). Changeux is a Darwinist, and some neoDarwinians have advanced remarkably limited views of human nature (Polkinghorne 2005, pp. 41-55; Midgley 2010). Dawkins (1976, p. 2) argued that "we, and all other animals, are machines created by our genes... a predominant quality to be expected in a successful gene is ruthless selfishness. This gene selfishness will usually give rise to selfishness in human behavior..." Wilson (1975) accepted this implication. Changeux, however, does not.

The difference between Changeux and Polkinghorne reflects what they have read. Changeux has read, marked, learned and inwardly digested Darwin's (1871) Descent of Man, which argues convincingly that human beings inherited their social insects from their social primate ancestors, which could not afford to act like egoists. Polkinghorne, by contrast, read neoDarwinians with an overly one-dimensional view of human beings, such as Wilson (1975), whose view of human nature is as limited as that of any economic determinist, but not other Darwinians who view human beings in an ampler social and intellectual context, such as Lorenz (1978), Durham (1991) and Changeux and Ricoeur (2000). Polkinghorne (2005), moreover, failed to recognize that faculties such as 
language, conceptual thought and reason that enhanced survival, ability to cooperate or attractiveness to mates, could also find other, unexpected uses, such as theoretical physics or music. Indeed, Changeux would have been wise to emphasize that faculties evolved for one purpose often find other, sometimes life-transforming uses.

Whether, and if so how soon, the research program Changeux outlines here will attain its goal, I cannot say. I do not think that someone who has exposed his work to criticism by a moral philosopher of the stature of Paul Ricoeur has a seriously inadequate view of what it means to be human. I think Changeux's project is worth doing, indeed, of exceptional interest. In sum, I recommend this book as a genuinely useful attempt to bridge the sciences and the humanities. It gives the reader a lot to think about.

\section{Compliance with ethical guidelines}

\section{Competing interests}

The author declares that he has no competing interests.

Received: 11 September 2015 Accepted: 12 September 2015

Published online: 25 September 2015

\section{References}

Bernanos G. La Liberté: Pour Quoi Faire?. Paris: Gallimard; 1953.

Boehm C. Impact of the human egalitarian syndrome on Darwinian selection mechanics. Am Nat. 1997;150(supplement 1):S100-21.

Boehm C. Moral origins: the evolution of virtue, altruism and shame. New York: Basic Books; 2012.

Changeux J-P. Neuronal man: the biology of mind. New York: Pantheon Books; 1985.

Changeux J-P. Raison et Plaisir. Paris: Odile Jacob; 1994.

Changeux J-P. Neuronal man: the biology of mind, paperback edition. Princeton: Princeton University Press; 1997.

Changeux J-P. The physiology of truth: neuroscience and human knowledge. Cambridge: Belknap Press; 2002.

Changeux J-P. Du vrai, du beau, du bien: Une nouvelle approche neuronal. Paris: Odile Jacob; 2008.

Changeux J-P, Connes A. Conversations on mind, matter and mathematics. Princeton: Princeton University Press; 1995.

Changeux J-P, Ricoeur P. What makes us think? A neuroscientist and a philosopher argue about ethics, human nature, and the brain. Princeton: Princeton University Press; 2000.
Damasio A. Looking for Spinoza: joy, sorrow and the feeling brain. Orlando: Harcourt; 2003.

Darwin C. The descent of man and selection in relation to sex. London: John Murray; 1871.

Darwin C. The expression of the emotions in man and animals. London: John Murray; 1872.

Dawkins R. The selfish gene. Oxford: Oxford University Press; 1976.

Durham WH. Coevolution: genes, culture and human diversity. Stanford: Stanford University Press; 1991.

Haldane JBS. Science and theology as art forms. In: Haldane JBS, editor. Possible worlds. London: Chatto and Windus; 1927. p. 225-40.

Haldane JBS. The causes of evolution. London: Longmans, Green and Co; 1932.

Hamilton WD. The genetical evolution of social behavior. J Theor Biol. 1964;7:1-51.

Jolly A. Lemur social behavior and primate intelligence. Science. 1966;153(3735):501-6.

Leigh EG Jr. The group selection controversy. J Evol Biol. 2010;23:6-19.

Lorenz K. Behind the mirror: a search for a natural history of human knowledge. New York: Harcourt Brace Jovanovich; 1978.

Marsh AA, Stoycos SA, Brethel-Haurwitz KM, Robinson P, VanMeter JW, Cardinale EM. Neural and cognitive characteristics of extraordinary altruists. PNAS. 2014;111(42):15036-41.

Midgley M. Heart and mind: the varieties of moral experience. New York: Routledge; 2003.

Midgley M. The solitary self: Darwin and the selfish gene. Durham: Acumen; 2010.

Midgley M. Are you an illusion?. Durham: Acumen; 2014

Monod J. Chance and necessity. New York: Vintage Books; 1971.

Nussbaum MC. Poetic justice: the literary imagination and public life. Boston: Beacon Books; 1995

Nussbaum MC. Political emotions: why love matters for justice. Cambridge: Belknap Press; 2013.

Polkinghorne J. Exploring reality: the intertwining of science and religion. New Haven: Yale University Press; 2005.

Prigogine I. Time, structure and fluctuations. Science. 1978;201(4358):777-85.

Putnam H. Renewing philosophy. Cambridge: Harvard University Press; 1992.

Smith A. An inquiry into the nature and causes of the wealth of nations. London: Strahan and Cadell; 1776.

Thornton A, McAuliffe K. Teaching wild meerkats. Science. 2006;313(5784):227-9.

Waley A. Three ways of thought in ancient China. Stanford: Stanford University Press; 1982.

Weyl H. Philosophy of mathematics and natural science. Princeton: Princeton University Press; 1949

Weyl H. Symmetry. Princeton: Princeton University Press; 1951.

Wilson EO. Sociobiology: the new synthesis. Cambridge: Belknap Press; 1975.

\section{Submit your manuscript to a SpringerOpen ${ }^{\circ}$ journal and benefit from:}

- Convenient online submission

- Rigorous peer review

- Immediate publication on acceptance

- Open access: articles freely available online

- High visibility within the field

- Retaining the copyright to your article

Submit your next manuscript at $>$ springeropen.com 